\title{
THE DIY CaReERs of TeCHNo AND DRUM 'N' BASS DJS IN VIENNA
}

\author{
$\longmapsto$ Feature Article $\longrightarrow$ \\ ROSA REITSAMER \\ UNIVERSITY OF VIENNA
}

\begin{abstract}
This article is based on empirical research into electronic dance music scenes in Vienna, Austria, and explores an area of cultural production that unites the ideology of creativity with the aspirations of social networks and individual entrepreneurship. It demonstrates how the role of a DJ can extend beyond merely playing records in public to embodying a hybrid of inspired musician, compelling performer, marketing genius and business strategist. An economically successful career does not depend only on performing in clubs. DJs are also involved in making music on computers, releasing records, marketing themselves through the media, organising club nights and running record labels. Social and cultural capital is invested in creative freedom, a DIY ethos and collective enjoyment, yet these DJs tend to promote the neoliberal economic ideal of an autonomous cultural entrepreneur, combining self-organisation and self-marketing with unregulated labour and gendered constructions of artistic identity. Taking Bourdieu's work on the field of cultural production as a theoretical framework, the analysis of modes of self-(re)presentation employed by Viennese techno and drum ' $n$ ' bass DJs suggests that the distinction of art from commerce, as proposed by Bourdieu (1993, 1996), tends to dissolve.
\end{abstract}

KeYwORDS: DIY careers, DJs, techno, drum 'n' bass, music scenes, Vienna, Bourdieu

Dr. Rosa Reitsamer is a lecturer in sociology at the University of Vienna where she teaches courses in youth culture and ethnography. She has co-edited the book "They Say I am Different..." Popularmusik, Szenen und ihre Akteure (2011, Löcker), and her monograph When Will I Be Famous? The Do-It-Yourself Careers of DJs will be published in 2011. Her publications address the questions of how agency is achieved in youth cultures and music scenes and how gender and ethnicity are negotiated by cultural producers.

Dancecult: Journal of Electronic Dance Music Culture 3(1): 28-43

ISSN 1947-5403 @2011 Dancecult http://dj.dancecult.net

DOI 10.12801/1947-5403.2011.03.01.02

\section{dsencecult \\ JOURNAL OF ELECTRONIC DANCE MUSIC CULTURE}




\section{INTRODUCTION}

IN THIS STUDY OF THE DIY CAREERS OF TECHNO AND DRUM 'N' BASS DJS in Vienna, Pierre Bourdieu's Work will be applied to explain the internal dynamics of the cultural fields. I will describe the techno and drum ' $n$ ' bass scenes in Vienna as subfields of restricted cultural production (Bourdieu 1996) within a supportive do-it-yourself industry (Peterson and Bennett 2004). I analyse the self-(re)presentation of eighteen DJs who are working in these two music scenes to show how these DJs define their creative roles and career development. This paper illustrates the importance that these DJs ascribe to scene networks (Hitzler and Niederbacher 2010) and their strategies for self-marketing to achieve regular performances at club nights, as well as the role of music production and the release of records in helping to make a DJ's career economically successful.

In describing the techno and drum ' $n$ ' bass scenes in Vienna and through an analysis of the self-(re)presentations of the DJs in my study, I will also demonstrate that Bourdieu's theory of cultural fields and the separation of these fields due to the opposition between art and commerce are only partially applicable to the context of these particular music scenes. Bourdieu $(1993,1996)$ introduces this opposition to separate the cultural fields into the subfield of mass production and the subfield of restricted cultural production: in the former, the production and sale of commercial cultural goods takes place and, as a result, the cultural producers are commercially successful because their aim is to make "the trade in cultural goods just another trade" (Bourdieu 1996: 42); this subfield is characterised by its heteronomous position in relation to economic and political fields of power which result in high concentrations of economic capital, yet gain low levels of cultural and symbolic capital. However, the latter subfield, that of restricted production, has a relatively autonomous position in relation to the field of power and an inverted distribution of capital; here, the cultural producers follow a logic of "anti-'economic' economy" (Bourdieu 1996: 142), which manifests itself in the disavowal of economics and the accumulation of cultural and symbolic capital. The "opposition between art and money" (Bourdieu 1996: 162), therefore, is based on the different logics that are followed in the two cultural fields as well as the degree to which the fields of cultural production are autonomous or heteronomous from the broader field of power.

My analysis of interviews with Viennese techno and drum ' $n$ ' bass DJs shows how the opposition between art and money has been eroded. The changing relations between culture and society, and between art and money, associated with neoliberal economics and post-Fordist models of industry increasingly force cultural producers to adopt an entrepreneurial position. This position is reflected in the self-(re)presentations of the DJs. Their habitus - the link between objective social structures and the individual-seems to embody post-Fordist social structures, while the illusio-a discursively-produced sense of absolute truth that develops with the habitus - marks a break with anti-commercial notions of creative activities. Redefining work, the DJs unite enjoyment, self-realisation and economic interest. The DJs interviewed for my study use the term "Me Inc." to describe 
their self-employed status and link this status with social networking and self-marketing, as well as with an ideology of autonomous creativity, thus promoting the neoliberal economic ideal of an autonomous cultural entrepreneur. I will draw upon the conception of network sociality (Wittel 2001) and analysis of new patterns of self-employment (Bröckling 2007; Bologna 2006; McRobbie 2002) to demonstrate that the modes of self-(re)presentation of DJs in Vienna share numerous characteristics with the entrepreneurial self (Bröckling 2007) and the new autonomy (Bologna 2006). Additionally, this study will also provide insights into the gender-specific self-(re)presentations of the DJs and the gendered construction of artistic identity.

An important part of the empirical basis for this analysis are eighteen qualitative face-to-face interviews with DJs from Vienna's techno and drum ' $\mathrm{n}$ ' bass scene, who provided information about their own self-(re)presentations and the shared, field-specific requirements for an economically successful DJ career in Vienna. The interviews were complemented by a virtual ethnography (Hine 2000), exploring the use by these DJs of social networking platforms such as MySpace. The main selection criterion for DJs to be interviewed for this study was that they make their living from their DJ activities and music production. The majority of the interviewees also supplement this work by organising club nights. The interviews focused on these DJs' entry into the music field as fluid transition from music fan to DJ; and from DJ-ing to music production; and their entrepreneurial networks and strategies of self-promotion. The DJs were between 18 and 42 years old at the time of my study and included eight women and ten men. All interviews were conducted in German. I have translated the quoted passages from German to English and the names of all the DJs have been changed to preserve their anonymity. The description of the techno and drum ' $n$ ' bass scenes is based on my research in the archives of the Viennese weekly magazine Falter, the two music magazines Skug: Journal für Musik and Resident: Drum \& Bass Magazine, and sixteen interviews with music journalists, club owners and musicians in Vienna.

\section{Vienna's TeChNo AND Drum 'N' Bass SCEne}

IN VIENNA, the capital of Austria and a city with approximately two million inhabitants, the techno and drum ' $n$ ' bass scenes have received scarcely any media or political attention. Vienna's historical lack of interest in contemporary popular music, including rock, pop and electronic genres, is rooted, to a large extent, in the more marketable image of Vienna as the City of Music, that is to say classical music (Horak and Mattl 2001; Nussbaumer 2007). The relative importance of classical for the city authorities can be seen in, among other things, the low level of subsidies to pop-cultural fields compared with those granted to "high culture" endeavours (Mokre 2007: 93). However, the relationship between political representatives and the fields of popular culture is changing with the growing influence of the creative industries in Europe, whose artistic and innovative content is expected to make a significant contribution to the economic boom of post-industrial cities (e.g. Florida 2002; Howkins 2001). In Vienna, the government's promotion of creative industries ${ }^{1}$ since 2000 has connected the demand for 
the commercialisation of art and high culture to the "festivalisation of the culture industry" in the $1980 \mathrm{~s}^{2}$ and to the opening of high culture to broader, partially disadvantaged and young audiences in the 1990s (Mokre 2007: 92). The techno and drum ' $n$ ' bass scenes in Vienna are influenced by these restructuring processes: as subfields of restricted cultural production, they relate to the broader local, national and global fields of culture, politics and economy (Webb 2007: 34-35) and operate in the transitional spaces between difference and homogeneity, locality and global networks (Peterson and Bennett 2004: 3). These scenes are, therefore, not autonomous, either from the dominance of large-scale institutions within the subfield of mass production or from the larger field of power (Hesmondhalgh 2006; Strachan 2007). However, the supporting DIY industry of both the drum 'n' bass and techno scenes contrasts with the subfield of mass production, because the former is largely "the domain of small collectives, fans turned entrepreneurs and volunteer labour" (Peterson and Bennett 2004: 5) while the latter is based on a globally-operated music industry dominated by a few media conglomerates. How did the DIY industry of the techno and drum ' $n$ ' bass scenes in Vienna develop in this context?

The Viennese techno scene formed at the beginning of the 1990s with (partly illegal) raves in parking lots and abandoned warehouses on the outskirts of the city. Its DIY industry reached its first economic peak between 1995 and 2000, with an estimated 45,000 visitors to the Free Parade in 1997, the opening of more than thirty clubs and bars for electronic music, and the music festivals Wien Soundsphere in 1995 and phonoTAKTIK in 1995 and 1999. This was also the time when new independent techno labels (e.g. Cheap Records, G-Stone Records, mego) appeared in Vienna. During this period, municipal policy in Vienna developed a stronger interest in rock, pop and electronic music and embedded the opening of numerous bars and clubs into the Urban Wien Gürtel Plus gentrification project (1995-2000), which was aimed at restructuring a part of the Vienna Gürtel-a wall construction supporting an elevated train which divides the inner city districts from the outer suburban districts. The Vienna techno scene gained international attention in the late 1990s through such DJs, music producers and label owners as Pulsinger \& Tunakan, Kruder \& Dorfmeister and dZihan \& Kamien (Reynolds [1998] 2008: 385), who were marketed together with other exclusively male DJs as Vienna Electronica (Astner 2006). In the view of many long-time scene actors, Vienna Electronica, along with Austropop (Larkey 1993), formed a counterpoint to classical music - and, thus, to the image of Vienna as the City of Music. The Vienna Tourist Board, meanwhile, integrated rock, pop and electronic music into the image of Vienna as the City of Music and began promoting relevant venues on its website. ${ }^{3}$

The drum ' $n$ ' bass scene in Vienna came into being in the mid-1990s, a few years after the techno scene, and until just before the turn of the millennium remained small. Only through the weekly Trife Life club nights (from 1999) and the radio show Dog's Bollocks, on the state youth radio station FM4, has a DIY industry formed to strengthen and expand this music scene. After Trife Life came to an end in 2005, many new DJ crews and event organising groups appeared, including the Urban Art Forms music festival. With the sponsorship of banks, breweries, distilleries and telecommunications firms, the Urban Art 
Forms festival is able to invite international drum 'n' bass and techno DJs to perform, and the festival draws about 40,000 music fans annually. Moreover, DJs and music producers have founded their own record labels (e.g. Ill.Skillz, High Tension Recordings) and committed drum ' $n$ ' bass fans operate numerous Internet forums (e.g. http://www.drumandbass.at) as well as the magazine Resident (in print 2005-08, online only since 2009).

These cultural and social practices of scene actors form an essential part of the DIY industry of the music scenes through which symbolic, social and cultural capital, as well as commodified goods, are circulated, invested and exchanged. According to Bourdieu's definition of cultural fields, scene actors are players who struggle for the best possible position in the cultural field by accumulating the kinds of capital favourable to them. For Bourdieu $(1993,1996)$ the only legitimate accumulation in the subfield of restricted production is symbolic and cultural capital; for DJs, this, I argue, means making a name through DJ performances and related activities, such as releasing recordings and/or programming music events.

\section{Access to DJ Performances at Club Nights}

ALL OF THE DJS who were interviewed for this study began their careers by playing records to entertain groups of people in clubs and bars of the local music scene. Once their careers advanced, most found work at clubs, dance events and international music festivals outside Austria, whereby they gradually became known within the scene and started to earn a living from their DJ appearances. ${ }^{4}$ The interview subjects describe how they got their first and subsequent appearances at clubs in Vienna. They comment on the importance of scene networks-including DJ crews, organisational elites and music production associationsand self-marketing for getting performances and making a name as a DJ. The interviews also show the gender-specific self-(re)presentations of the DJs.

Sebastian, a techno DJ, entered the business in the early 1990s. He got his first gig by organising club nights:

I started spinning records in '91. That was at the time that techno had taken off so extremely, and I was there, because we had made the first techno parties in Vienna, where I DJ-ed. It was enormous luck that I was at the right place at the right time, and then everything totally took off. ${ }^{5}$

This DJ presents himself as a co-founder of the Viennese techno scene, which formed slowly in the early 1990s and, within a few years, experienced a tremendous increase in cultural, symbolic and economic capital. That he profited from the increasing popularity of the Viennese techno scene and became known at the beginning of his DJ activities through performances at self-organised club nights—and as a consequence could increase the number of his appearances-he attributes to chance, to being at the right place at the right time. Thus, he conveys the impression that a successful DJ career cannot be planned, because his own career flourished as a result of good fortune. Paul, a drum ' $n$ ' bass DJ, pursued a different path to getting appearances at club nights at the beginning of his career. 
His self-presentation resembles that of Sebastian; however, he notes that:

I always went to the Trife Life parties, where I also got to know the guys from Trife Life. We were on the same wavelength and since I was already pretty good at spinning records at the time, they took me in. They let me play at their parties and whoever could DJ with Trife Life was immediately in demand. You have to be at the right place at the right time to get a chance. The rest is just practice, practice, practice, persevere and then get lucky too. ${ }^{6}$

Paul came to DJ performance first as a spectator, by regularly attending Trife Life club nights; not long after this time, he was admitted as a member into the Trife Life crew. This membership marked a turning point in his career, which seems again to deny any planning, because his success was due to the seemingly coincidental opportunity of working with an established DJ crew and impressing his colleagues and the audience with his DJ performance. The willingness to practice DJ-ing intensively at home and to demonstrate perseverance are defined as a prerequisites in order to be able to take advantage of the invitation to perform at club nights. Paul seems to have fulfilled these prerequisites, as he describes himself already starting a career as a "good" DJ, allowing him to accumulate crucial social capitalmembership in DJ and event crews-in order to gain DJ appearances at club nights.

Clearly evident in this narrative is the fact that DJ crews and organisational elites can exert considerable influence over the careers of unknown DJs, as the actors in these informal scene networks can extend invitations to perform at their club nights or not. This kind of inclusion or exclusion is instrumental in the definition and distribution of symbolic capital in music scenes-capital that DJs can obtain only through the recognition and valuation of their colleagues and other scene actors. The recognition and valuation of others was defined by Bourdieu as a feature of the cultural fields:

Few people depend as much as artists ... do for their self-image upon the image others, and particularly other artists and writers, have of them. 'There are,' writes JeanPaul Sartre, 'qualities that we acquire only through the judgement of others'. This is especially so for the quality of a writer, artist or scientist, which is so difficult to define because it exists only in, and through, co-optation, understood as the circular relations of reciprocal recognition among peers. Any act of cultural production implies an affirmation of its claim to cultural legitimacy (Bourdieu 1993: 16).

While Paul and Sebastian received this recognition from the scene networks, all of my female interviewees described how, especially in the beginning, the informal scene networks ignored their DJ activities. As DJ Sara explains:

I always notice that I cannot gain access to the male networks. The guys don't want to have anything to do with you as a woman, and certainly not when you're starting out. They mutually invite one another, regardless of whether they have a good selection and can mix or not, and they sit and talk about music as if it were a science, and make collaborative music. And then I had the idea to develop my own structures, and even make my own club. This way, I got more bookings, but it was hard work. ${ }^{7}$ 
Sara locates her lack of integration into "male networks", with closed borders and firmly defined membership, not as an isolated social phenomenon that only she had experienced. Fundamentally, unknown female DJs have difficulty in securing a legitimate position in music scenes because of their gender (Farrugia 2004: 244-246), and their exclusion from scene networks means that they can accumulate neither social nor symbolic capital. Sara argues that even the social capital of unknown male DJs at the start of their careers, which is expressed in their membership in a "male network", is more important in successfully starting their careers than their "subcultural capital" (Thornton 1996: 11), ${ }^{8}$ such as an appealing choice of music ("selection") and beat mixing technique, which actually affects their performance as a DJ (Montano 2009: 83-87).

Sara compensated for her exclusion from male-dominated scene networks by organising her own regular club nights, to which she invited other DJs and where she herself performed. In contrast to Paul and Sebastian, her self-presentation is based not on chance or luck, the way that the two male DJs justified their performances at club nights at the beginning of their careers, nor does she present herself as a co-founder of the techno scene or as a good DJ. Sara views the turning point in launching her career as labour-intensive event organisation, which gave her the advantage of starting her own informal scene network in which to gain the recognition of colleagues and club audiences. Self-organisation and work on the one hand, chance and luck on the other; these are the central concepts of genderspecific self-(re)presentations that result from inclusion into or exclusion from informal scene networks.

Regardless of these gender-specific aspects in their self-presentations, the stories of these three DJs illustrate that they got performances at club nights by supplementing their DJ work with organisational activities. With the exception of one techno DJ, all the interviewees took on this dual function of DJ and club host at the start of their careers. ${ }^{9}$ They occupy a decision-making position in the music scenes, which allows them to participate in the game of recognition and power, thereby affecting the career progression of the next generation of DJs significantly.

Sara, a successful techno DJ and club promoter, explains her criteria for inviting DJs to play at the club nights she runs:

Young DJs who want to play-there are so many. The question is: should you give them the opportunity or not? I say probably not, because the risk is too great. At my club, the quality and seriousness of the DJs is in the foreground. They have to be not only DJs but also music producers, and they must make it their full-time job and live by it. My club is in the avant-garde of techno culture and I cannot afford to have people suddenly stay away. ${ }^{10}$

The granting of opportunities to up-and-coming DJs hinges on the quality of the DJs. For Sara, this also means that DJs must be active as music producers and be able to live entirely on their DJ work and music production. Her standard links quality and seriousness with economic success in a way that suggests not only that quality leads necessarily to success but 
also that success can be taken as a sign of quality. Quality, therefore, takes on a dual role in Sara's invitation policy: it serves as a "difference marker" between established and up-andcoming DJs, while at the same time, using a particular economic yardstick for determining quality (i.e., whoever earns enough money is good), the invitation policy's ostensible focus on quality becomes market orientation.

With this specific definition of quality, Sara blurs the opposition between art and money. The "avant-garde" status to which she lays claim is associated with high quality and serves to distinguish her club from the so-called mainstream of techno music. In this case, a "strategy of distinction", as Bourdieu (1984) would put it, manifests itself not by a rejection of economic logic, as he would expect; instead, in the process of accumulating cultural, social and symbolic capital, established economic status is a prerequisite. This policy in artist programming ultimately makes it impossible to invite unknown DJs to perform at club nights. These DJs seem to pose the "risk" that their lack of popularity would make them attract too few music fans, thereby reducing the revenue from the event, not to mention its intangible credibility.

My interviewees all say that they constantly have to intensify their efforts at getting DJ gigs, and not only at the start of their careers. They are preoccupied with self-promotion to increase their performances at club nights and music festivals. For this purpose, all of the DJs interviewed use, in addition to local scene networks, the Internet social networking platform MySpace to present and promote their musical activities and to socialise with scene members, especially with other DJs and club hosts, and to arrange appearances at club nights in music scenes outside Austria. DJ Paul even explained that his extensive use of MySpace allowed him to cancel his contract with a booking agent because he can now easily manage his own self-promotion and organise his club night appearances using the Internet. DJ Pia also talks of self-promotion in conjunction with the acquisition of DJ performances:

I need a lot of time for my self-promotion because I go out often to meet people and I must update my websites regularly and do all that stuff on the internet. That's really time-consuming but it's very, very important that you have your networks. But I also need a lot of time to train myself artistically to improve my DJ-ing and music making takes also a lot of time and also all the gigs, especially if you go abroad. But I am selfemployed and I can decide for myself when I want to do what and how big or small my business is. I make all decisions according to my personal energy and my time and my resources. As a Me Inc., I can control this very well. ${ }^{11}$

For this DJ, self-marketing means maintaining and expanding her (trans-)local and online networks by using new media technologies and meeting people at parties. Hence, as well as places to meet friends, parties become networking events to build co-operation with other DJs, music producers, club hosts. They symbolise the perfect symbiosis of work and leisure whereby DJ Pia can scarcely distinguish between friends and work colleagues. Such on- and off-line networking practices aimed at producing intensive, short-term relationships, along with the blurring of the boundaries between work and leisure and between friends and 
colleagues, amount to what Andreas Wittel (2001) calls network sociality. This sociality is regarded as essential for an economically successful career (Wittel 2001: 65-66; McRobbie 2002: 519). For Pia, network sociality is, in addition to all her other activities, timeintensive. Through the continuous overlapping of DJ-ing, music production, networking, the acquisition of DJ performances and self-marketing, she performs an "intensification of working hours" (Bologna 2006: 21) in which her working time normally exceeds an eight-hour day. Pia describes her employment status, which allows her to combine all the different activities and determine the size and scope of the business according to her personal resources, with the term "Me Inc.". This expression is used in self-help literature for the propagation of the entrepreneurial self (Bröckling 2007) and the new autonomy (Bologna 2006), which suggests an understanding of one's own work no longer as cultural and social practices but as services and goods. DJs tend to embody this theoretical proposal in their habitus (Bourdieu 1996). Pia's self-image is that of an autonomous cultural entrepreneur. This neoliberal economic ideal, based on the idea of controlling one's own career path through self-organisation, self-marketing and social networking, is, in practice, associated with unregulated labour and gendered constructions of artistic identity. But how important are producing music and releasing records for an economically successful DIY career?

\section{Making Music-Producing Records}

MY INTERVIEW SUBJECTS have all expanded their DJ activities at different times to include the related creative activity of music production by making original music compositions as well as remixes of existing songs. The majority of the male DJs, however, began performing as DJs while simultaneously making music on computers and, at the time of my study, had already released many more recordings than their female colleagues. Nonetheless, they all describe the learning of music production as a time-consuming and difficult process. As drum 'n' bass DJ Peter puts it:

I bought all the equipment and started making music and I immediately thought, I can't do it (laughs). I didn't get it, because it has so much to do with facts and figures, and I nearly lost hope more than once.... And as I got halfway decent at it, it still took two years before I released my first track, because you also have to find a label. That's also not so easy. ${ }^{12}$

In addition to learning music production on the computer, ${ }^{13}$ the search for a record label provides many DJs with a new hurdle, which they commonly attribute to the "crisis of the music industry" and the lack of distribution networks for rock, pop and electronic music in Austria (Gebesmaier 2001). Seven of the eighteen DJs interviewed for this study circumvented this hurdle by starting their own record labels, on which they release primarily their own music and co-operate with smaller distributors in Germany (for techno recordings) and the UK (for drum 'n' bass recordings). But the economic payoff for the DJs after the release of their disc-following heavy investments of time, effort and money-is small. According to the information provided by the DJs interviewed, the sales of their 
recordings range from 100 to a maximum of 3,000 units (including MP3 downloads), and there is normally no profit after covering costs of production and promotion.

This raises the question of why DJs still pursue music production and (want to) release their music on record labels. DJ Perry gives an answer:

Of course it gets DJs bookings if they've brought out a record. It shows you're not just some DJ who spins vinyl, but you've made some good tracks and been released on a label. Then there's no longer the question if you belong on the scene. It's just clear. I'm OK with this. ${ }^{14}$

Perry cites three reasons why DJs make music and release records. Firstly, with the release of a record, DJs secure their status as a cultural producer in the music scene while transforming their (sub)cultural capital into a commodity. Secondly, they can increase their chances of being booked for gigs more often by club organisers because of the recognition they get from their released records. Finally, with a record release DJs can produce distinctions because they can distinguish themselves from all those DJs who do not follow this cultural practice. DJ Perry seems to be referring to a consensus in the Viennese electronic dance music scene that sets up an additional key requirement for an economically successful DJ career: the release of a record on one of the more prestigious record labels. ${ }^{15}$ None of the DJs interviewed for this study actually earned enough from their record sales or royalties to make a living. Their performances at club nights are, therefore, their primary source of income. Samira, a female techno DJ who started spinning records in the early 1990s and released her first records three years later, asserts this fact once again by addressing the increasing requirements of DJs for an economically successful career:

Just being a good DJ is no longer sufficient today. In the time of the older generation, this was not the case. But the successful DJs of today have all produced a super record that was accepted internationally. They can then earn really good money by DJing because they can get lots of bookings and raise their fees. Of course, it also means that you can DJ really well, because there are ridiculously, really ridiculously many good DJs that are just not known. ${ }^{16}$

Samira distinguishes between two generations of DJs in the application of different criteria for success: for the first generation of DJs from the early days of the Viennese techno scene, to which she belongs, being a good DJ was enough to develop an economically successful career. Producing music and releasing recordings was an option but not a requirement for success. The second, current generation has come to DJing at a time when the DIY industry of the Vienna music scene is already thriving and a greater number of young people are discovering this activity as a potential career option. This generation is required to be both a DJ and a music producer. They have to make a name for themselves not only by winning over the club audience with good DJ performances, but also by releasing recordings of international standard. By this, Samira means that the music and, specifically, the records of those DJs are purchased, discussed in music magazines (e.g. de:bug, Spex, DJ Mag, The Wire) 
and played on radio broadcasts and at DJ performances. This field-specific recognition, which can extend far beyond the boundaries of the local music scene, is the DJ's (sub) cultural capital through which they make an international name for themselves as music producers. DJs can use this popularity to increase their number of appearances at club nights along with their fees.

Samira, therefore, assumes that the investments of second generation DJs might be worthwhile because at least a few earn their living from their DJ performances and music production work. With this assumption, she expresses her illusio (Bourdieu 1996), which describes the DJ's "faith" in the "game" of recognition and her interest in participating in this game, which puts the DJs in competition with one another in the struggle for a legitimate position in the music scenes. For Bourdieu, the illusio of cultural producers in the subfield of restricted cultural production is characterised by an economic disinterest. The DJs interviewed, at first glance, share this lack of interest in an economically successful career. Without exception, they all emphasised that they had come to DJ-ing and music production because these activities were fun:

I am often asked by people how to be successful. That is, as a principle, misguided. You should spin records and make music in order to play what you like and because it's fun. Then you will also be successful. ${ }^{17}$

The illusio that can be recognised in Paolo's self-presentation as a successful DJ does not preclude his economic interests. Rather, he combines fun and self-realisation with economic interests. The prerequisite for Paolo's illusio is his strong personal identification with his cultural practices. This identification flows into a redefinition of work and, on this basis, is supposed no longer to lead to heteronomy and alienation but rather to a self-realisation that makes it possible to have fun while making a living (McRobbie 2002: 518). Such an illusio may explain why the interviewed DJs are convinced that, with the release of good records and the achievement of good DJ performances, the corresponding self-marketing and membership in scene networks is achieved and inevitably leads to an economically successful DIY career. DJ Tina has fulfilled most of these field-specific requirements, but blames her lack of career success on the fact she has not yet released a well-received record:

I have to date only released one track [an original composition], and that disappeared pretty quickly, unfortunately. But I need just one good record. I don't have it. I should tackle that urgently and immediately, because otherwise I won't make it. ${ }^{18}$

Unlike Tina, Peter and his colleagues have released successful records. He views the decisive criterion for their success as the "ideas" that they implement in music production:

We have a track called [name of song] that appeared on [name of British drum ' $n$ ' base record label]. Through this, we became known worldwide, by drum ' $n$ ' bass standards. Then our market value suddenly increased and we were in all the sales charts, download charts, magazines, anything. We've really made something new and pushed the boundaries of drum ' $n$ ' bass. There had previously been attempts at making such a thing, but we really implemented the idea. ${ }^{19}$ 
John Howkins (2007: 118) defines creativity as "having a new idea" that should fulfil the four criteria of "personal, original, meaningful and useful (POMU)" so that it leads to innovation and receives an economic value. This definition of creativity is part of a series of powerful economic discourses that aim to establish a new relationship between culture and the economy through the growing emphasis on creative industries. As a result, creativity in post-Fordist capitalism has become what "efficiency" was to the bureaucratic corporations of the twentieth century (e.g. Boltanski and Chiapello 2007): that mysterious individual and collective quality which distinguishes the successful from the unsuccessful (Gilbert 2011: 78). It is, therefore, no surprise that DJ Peter refers to innovating ideas in music production to explain his success.

The techno and drum ' $n$ ' bass DJs I have interviewed rarely develop their music production ideas alone. They co-operate with musicians, singers, instrumentalists and music producers, by learning music production from each other, lending one another equipment, exchanging music software and making music together. DJ Florian has been working with two other DJs for several years. They share a music studio and invite other artists for the realisation of different music projects. In his interview, he talks about the payment of his partners:

We [Florian and his two colleagues] are working with many, many different musicians and singers. If we get subsidies for the releases, we will pay the artists but many of them say: Okay, I will sing for your track and you produce a few beats for me. That's family business where one says: I look after you and you look after me-be it money or a different kind of exchange. And that works really well because we are all friends and we have ideas. ${ }^{20}$

In using the term "family business", the DJ wants to express his responsibilities to the artists involved, and their desire to be rewarded appropriately for their finished work, at least through the exchange of benefits, in order to bridge the period until they receive subsidies, for instance from Departure, the Viennese creative industries funding institution. The non-monetary exchange of benefits is based on the friendship of the musicians, on mutual support and trust, and this exchange can be defined as a part of the DIY industry of the music scenes. In music production, do-it-yourself therefore always also means do-ittogether, whereby musical creativity becomes a product of collaboration and co-operation between musicians, DJs, producers, technicians and others (Toynbee 2000).

In these DJs' self-image, creativity is a highly individual (sub)cultural capital that, as with their symbolic capital, they (want to) convert into money through their DJ performances at club nights - albeit in a roundabout way through the release of records. The illusio that these DJs develop is expressed in their ideas about success and failure as well as in the use of economic terminology, whereby their collaboration in music production becomes a "business" (DJ Florian), the release of "good" records contributes to an increase in their economic "market value" (DJ Peter) and economic standards help determine the quality of DJ performances (DJ Sara). These aspects of the shared illusio, which link anti-economic with economic logic, form the basis of the DJs' self-image as autonomous cultural entrepreneurs. 


\section{CONCLUSION}

IN THIS ARTICLE, I have presented my exploration of the DIY careers of techno and drum ' $\mathrm{n}$ ' bass DJs in Vienna in the context of neoliberal developments in the music scenes. Bourdieu's notions of capital, habitus and field were valuable tools both in the analysis of the empirical data and in showing that the conclusions Bourdieu himself drew from the detailed investigation of the genesis and the structure of the last century's literary field require some modifications in the light of the new relations between (youth) culture, the arts and economics and the corresponding new patterns of self-employment. The above study of the experiences of cultural producers such as electronic music DJs has shown that the distinctions between the subfield of restricted cultural production and the subfield of mass production that Bourdieu drew according to the opposition between art and money do not hold for electronic dance music scenes. During the 1990s, the techno and drum ' $n$ ' bass scenes in Vienna were already becoming economically potent youth cultural fields, exhibiting numerous interconnections with the institutions in the field of power. These music scenes are, thus, not elite cultural fields that represent the taste of a distinguished social group, nor do the musical activities of the DJs comply with cultural and social practices of an elitist group of artists. The DJ's habitus (Me Inc.) and their network sociality corresponds, rather, with what is expected of all workers under a neoliberal economic regime-namely to demonstrate responsibility for one's own life and to prove creativity in the organisation of the work/life balance through self-organisation, self-marketing and intensive strategies of social networking. The DJs seem to embody these post-Fordist social structures and, therefore, they call into questions certain assumptions about "creative" professions, such as the disavowal of commerce and the supposed autonomy of cultural producers. However, despite the erosion of the opposition between art and money, traditional assumptions about the life of the artist still survive in the illusio of the DJs and apparently do not contradict their economic and social habitus. My interview subjects defined themselves as "avant-garde" DJs, music producers and club hosts, and distanced themselves from the mainstream-in Bourdieu's terminology, the subfield of mass production. The DJs' narratives, moreover, gave the impression that their notions of being "free" cultural producers still embody gendered constructions of artistic identity. Such self-(re)presentations ultimately result in an intensification of the neoliberal competitive entrepreneurial model, especially for women who wish to enter the field and make a living with their creative activities. This reproduction of social gender inequalities is one of the central problems with the creative industries model and the new patterns of self-employment that are being popularised today. Or, in conclusion, to say it in Angela McRobbie's words: "What we see ... is the emergence of working practices which reproduce older patterns of marginalization (of women and people from different ethnic backgrounds), while also disallowing any space or time for such issues to reach articulation" (2002: 523). 


\section{ACKNOWLEDGEMENTS}

I would like to thank Anthony Auerbach for valuable discussions during the preparation of this article. In addition, I am also grateful for the suggestions made by both anonymous peer reviewers.

\section{ENDNOTES}

1 The state promotion of creative industries in Vienna can be seen in, among other things, the establishment of the departure funding institution for "creative professionals" $<$ http://www.departure.at> or the opening of Museumsquartier (Quartier 21), a culturalindustry cluster consisting of museums, restaurants, clubs and bars.

2 For the fields of popular culture, this "festivalisation" manifests itself with the first music festivals organized by institutions of high culture with a focus on rock music: in the 1980s, as part of the Wiener Festwochen, the music festivals Töne und Gegentöne (1983), Junge Festwochen (1987), Cosmo-Kinetical Theatre Red Pilot (1988) and Big Beat (1989) took place.

3 Vienna Tourist Board <www.wien.info/de/lifestyle-szene/nightlife $>$.

4 The DJs indicated the following for their fees: drum ' $n$ ' bass DJs will make up to $€ 300$ for their performances in Austria; outside of Austria, they can make $€ 500$ to $€ 1,000$ and in rare cases up to $€ 3,000$. The fees for techno DJs range from $€ 300$ for performances in Austria to up to $€ 5,000$ - and in rare cases, more-for appearances in other European cities.

5 DJ, techno, male, interview with the author (Vienna), 26 May 2008.

6 DJ, drum 'n' bass, male, interview with the author (Vienna), 27 January 2008.

7 DJ, techno, female, interview with the author (Vienna), 16 May 2008.

8 Thornton defines subcultural capital as a specific form of Bourdieu's cultural capital (2004), which is not acquired through formal education and depends on notions of hipness.

9 The techno DJ who was not involved in organising club nights started her DJ activities while working as a record shop assistant. She was able to increase her appearances at club nights significantly because she met other DJs and club hosts in the course of her job.

10 DJ, techno, female, interview with the author (Vienna), 16 May 2008.

11 DJ, techno, female, interview with the author (Vienna), 26 September 2007.

12 DJ, drum ' $n$ ' bass, male, interview with the author (Vienna), 10 May 2008.

13 The overwhelming majority of the DJs interviewed have dispensed with the use of devices such as synthesisers or drum machines and produce their music only on the computer.

14 DJ, techno, male, interview with the author (Vienna), 23 August 2008.

15 The DJs interviewed rejected the possibility of publishing music exclusively on the Internet. They use digital download platforms only for the promotion and supplemental sale of their music.

16 DJ, techno, female, interview with the author (Vienna), 9 February 2008.

17 DJ, drum 'n' bass, male, interview with the author (Vienna), 27 January 2008.

18 DJ, techno, female, interview with the author (Vienna), 10 March 2008.

19 DJ, drum 'n' bass, male, interview with the author (Vienna), 10 May 2008.

20 DJ, drum 'n' bass, male, interview with the author (Vienna), 10 November 2007. 


\section{REFERENCES}

Astner, S. 2006. “Die Dynamik der Vienna Electronica”. Master’s thesis (Musicology), University of Vienna.

Bologna, Sergio. 2006. Die Zerstörung der Mittelschichten. Thesen zur Neuen Selbständigkeit. Graz and Vienna: Nauser \& Nauser.

Boltanski, Luc and Eve Chiapello. 2007. The New Spirit of Capitalism. London: Verso.

Bourdieu, Pierre. 1984. Distinction: A Social Critique of the Judgement of Taste. Trans. Richard Nice. Cambridge, MA: Harvard University Press.

- - . 1993. The Field of Cultural Production: Essays on Art and Literature. Cambridge: Polity Press.

- - - 1996. The Rules of Art: Genesis and Structure of the Literary Field. Cambridge: Polity Press.

- - - 2004. "The Forms of Capital". In The RoutledgeFalmer Reader in Sociology of Education, ed. Stephen J. Ball, 17-29. London and New York: RoutledgeFalmer.

Bröckling, Ulrich. 2007. Das unternehmerische Selbst. Soziologie einer Subjektivitätsform.

Frankfurt am Main: Suhrkamp.

Farrugia, Rebekah. 2004. "Sisterdjs in the House: Electronic/Dance Music and Women-Centred

Spaces in the Net". Women's Studies in Communication 27(2): 236-62.

Florida, Richard. 2002. The Rise of the Creative Class. New York: Basic Books.

Gebesmair, Andreas, 2001. "Die Entwicklung der österreichischen Popmusik im Zeitalter der Globalisierung 1979-2000”. In Adieu, Austropop? Die schwindenden Chancen der österreichischen Popmusik auf dem Musikmarkt (mediacult.doc 06/01), ed. Robert Harauer, 7-55. Vienna: mediacult.

Gilbert, Jeremy. 2011. "Kapitalismus, Kreativität und Kontinuität in der sonischen Sphäre”. In They Say I'm Different... Popularmusik, Szenen und ibre Akteure, ed. Rosa Reitsamer and Wolfgang Fichna, 78-93. Vienna: Löcker Verlag.

Hesmondhalgh, David. 2006. "Bourdieu, the Media and Cultural Production”. Media, Culture and Society 28(2): 211-31.

Hine, Christine M. 2000. Virtual Ethnography. London: Sage.

Hitzler, Ronald and Arne Niederbacher. 2010. Leben in Szenen. Formen juveniler Vorgemeinschaftung heute. 3., vollständig überarbeitete Auflage. Wiesbaden: VS Verlag.

Horak, Roman and Siegfried Mattl, 2001. “'Musik liegt in der Luft'. Die 'Weltkulturhauptstadt Wien' - Eine Konstruktion”'. In Stadt. Masse. Raum. Wiener Studien zur Archäologie des Popularen, ed. Roman Horak, Wolfgang Maderthaner, Siegfried Mattl and Lutz Musner, 164-239. Vienna: Turia + Kant.

Howkins, John. 2007. “The Major's Commission on the Creative Industries”. In Creative Industries, ed. John Hartley, 117-125. Malden, Oxford and Victoria: Blackwell.

Larkey, Edward. 1993. Pungent Sounds: Constructing Identity with Popular Music in Austria. New York: Peter Lang Publishing.

Lash, Scott, and John Urry. 1994. Economies of Signs and Space. London and New Delhi: Sage. McRobbie, Angela. 2002. "Clubs to Companies: Notes on the Decline of Political Culture in Speeded-Up Creative Worlds”. Cultural Studies 16 (4): 516-31.

Mokre, Monika. 2007. “Gouvernekreativität, oder: Die Creative Industries in Österreich”. In 
Kritik der Kreativität. ed. Gerald Raunig and Ulf Wuggenig, 92-102. Vienna: Turia + Kant. Montano, Ed. 2009. "DJ Culture in the Commercial Sydney Dance Music Scene”. Dancecult: Journal of Electronic Dance Music Culture 1(1): 81-93. $<$ http://dx.doi.org/10.12801/1947-5403.2009.01.01.05>

Nussbaumer, Martina. 2007. Musikstadt Wien. Die Konstruktion eines Images. Freiburg: Rombach. Peterson, Richard A., and Andy Bennett. 2004. "Introducing Music Scenes". In Music Scenes: Local, Translocal, and Virtual. ed. Andy Bennett and Richard A. Peterson, 1-16. Nashville: Vanderbilt University Press.

Reynolds, Simon. 2008 [1998]. Energy Flash: A Journey Through Rave Music and Dance Culture. London: Picador.

Strachan, Robert. 2007. "Micro-Independent Record Labels in the UK: Discourse, DIY Cultural Production and the Music Industry”. European Journal of Cultural Studies 10 (2): 245-65.

Thornton, Sarah. 1996. Club Cultures: Music, Media and Subcultural Capital. Hannover and London: Wesleyan University Press.

Toynbee, Jason. 2000. Making Popular Music. London: Arnold.

Webb, Peter. 2007. Exploring the Networked Worlds of Popular Music: Milieu Cultures. New York: Routledge.

Wien Info (Vienna Tourist Board): < www.wien.info/de/lifestyle-szene/nightlife $>$ (accessed December 2010).

Wittel, Andreas. 2001. “Towards a Network Sociality”. Theory, Culture \& Society 18 (6): 51-76. 